\title{
Combining Bromofluoropropene with Water Mist for Suppressing Deep Seated Wood Crib Fires
}

\author{
XIAOMIN NI ${ }^{1}$, W. K. CHOW ${ }^{2}$, SHAOGANG ZHANG ${ }^{1}$, MEI ZHAO ${ }^{1}$, ZHONG ZHENG $^{3}$, and \\ XISHI WANG ${ }^{1}$ \\ ${ }^{1}$ State Key Laboratory of Fire Science, University of Science and Technology of China, Hefei, \\ Anhui, China \\ ${ }^{2}$ Research Centre for Fire Engineering, Department of Building Services Engineering, \\ The Hong Kong Polytechnic University, Hong Kong, China \\ ${ }^{3}$ Department of Electronic Science and Technology, University of Science and Technology of \\ China, Hefei, Anhui, China
}

\begin{abstract}
Application of 2-bromo-3,3,3-trifluoropropene (BTP) with water mist in suppressing deep seated wood crib fires was reported in this paper. Performance of the combination of the two clean fire suppressants was examined by laboratory scale experiments and compared with water mist and BTP used alone. Results showed that coupling of water mist with BTP could extinguish the wood crib fires with high efficiency, in which BTP discharged first could fast extinguish the flame, and the following water mist could cool the wood surface and stop glowing combustion. As a result, a complete fire extinguishment without re-strike was achieved in short time. Furthermore, hydrogen fluoride (HF) acid gas produced in the suppression process was acceptable for the use of water mist in conjunction with BTP.
\end{abstract}

KEYWORDS: wood crib fires, suppression, water mist, bromofluoropropene, combination

\section{INTRODUCTION}

Wood crib fires as typical Class A fires have been widely used in the fire research for their good experimental repeatability of heat release rate in different burning scenarios. Behavior of wood crib fire is closer to real fire development in compartment than other fire resources [1]. Fire safety performance involved wood production is of international concern for fire safety reflected in design requirements of building codes [2]. Therefore, study on suitable agents and techniques for extinguishing this particular type of fire is of great importance. Different to liquid pool fires, solids have high surface temperature during burning [3]. The flame is the burning volatile components which are evaporate from the hot wood surface. Once the gas phase combustion is suppressed, a second combustion mechanism takes over if the heat content temperature of the crib is sufficient. This is the glowing combustion of the remaining cellulosic char. If unchecked, this glowing combustion will propagate, and the conducted and radiated heat may be sufficient to cause ignition of unpyrolysed wood, i.e. a re-strike will occur [4-6]. As a result, for deep seated wood crib fires, unless the wood crib is cooled appreciably, the fire would be re-ignited after flame extinction. Appropriate fire extinguishing agents should be selected for suppressing wood crib fires. Various kinds of fire suppressing agents have been explored for extinguishing wood crib fires, including water sprinkler, water mist, water mist with additives, foam, liquid nitrogen, dry powders, etc [7-14]. Sprinkler could effectively extinguish wood crib fires, but a great amount of water was consumed and would result in water damage. Foam might extinguish the flame but the emitted heat of wood would quickly destroy the foam blanket and re-ignite occured. Dry powders are also effective in extinguishing the flame. But the wood would rapidly re-ignite because gas and dry powders could not seal the wood surface from oxygen. Clean chemical gas such as heptafluoropropane and hexafluoropropene are efficient in suppressing many different kinds of fires. However, these clean gases are not effective for suppressing deep seated wood crib fires. They could fast extinguish the flame through chemical effect, however, gas is easily run away and could not effectively cool the wood surface. The smoldering wood crib would re-ignite soon after stopping discharging agents, especially in the compartments with good ventilation. 
Water mist is proposed for extinguishing wood crib fires. Experiments on extinguishing wood crib fires are reported by Liu and coworkers [15]. But only with relatively high pressure and long time discharging could extinguish the fires. Water mist under low pressure is difficult to penetrate the flame fume and exert its role of cooling. Therefore, special design and operation scheme must be prepared for suppressing deep seated wood crib fires by water mist. To improve the efficiency of water mist, various additives were added, including inorganic salts and some surfactants [16]. But such additives might be condensed and cleaning up the additive residue after a fire remains problems.

Clean and efficient agents for extinguishing deep seated wood crib fires without re-strike have been pursued by researchers. Considering the virtue and drawbacks of water mist and clean gas, here, it is proposed to combine water mist and clean gas together. Clean chemical gas is used to fast extinguishing the surface flame, then water mist is used to cool wood surface and stop the smoldering. Bromofluoropropene (BTP) is selected as the clean gas candidate. BTP as a new kind of high efficiency clean fire suppressant is a liquid at room temperature under atmosphere pressure [17], which could be discharged like water mist. As a result, the two agents could be discharged from the same discharging system. Previously, BTP with water mist was used to suppress gasoline pool fires [18]. In this paper, we attempted to verify the applicability of clean chemical gas and water mist together to suppress deep seated solid fires. Laboratoryscaled experiments were conducted in a $48 \mathrm{~m}^{3}$ room with natural ventilation. Four scenarios were studied, including water mist used alone, BTP used alone, BTP discharged followed by water mist, BTP and water mist discharged simultaneously, respectively. By comparing the fire extinguishing time and HF gas concentrations produced during the test, performance of the combining of BTP and water mist was examined. The role of BTP and water mist in the fire suppression was discussed based on experimental results and established fire suppression theories.

\section{EXPERIMENTAL STUDIES}

Generally, the standard testing procedures for extinguishing wood crib fires includes ISO-14520-1, NFPA 18, ANSI/UL 711, etc. However, in these standards, the cribs are quite large, which are expensive and time consuming to build, ignite and extinguish [6]. Correspondingly, a great amount of fire suppressant is needed, and the cost is greatly increased. For the limit of our experimental conditions, large fire tests following these standards were difficult to undertake. So reduced scale tests were designed with relatively small wood cribs and less extinguishing agent to reduce the cost. But the test methods were basically in conformance with the regulations of hand held extinguishers for wood crib fires.

A schematic diagram of the experimental setup is shown in Fig. 1. Experiments were conducted in a room of length $4.0 \mathrm{~m}$, width $3.0 \mathrm{~m}$ and height $4.0 \mathrm{~m}$ with natural ventilation. The wood crib is made of 100 fir sticks with diameter of $2 \mathrm{~cm} \times 2 \mathrm{~cm} \times 30 \mathrm{~cm}$ long arrange in 10 layers. The crib was supported $40 \mathrm{~cm}$ high above the ground, allowing good airflow through the crib during pre-bum. A gasoline pool pan with diameter of $20 \mathrm{~cm}$ was placed under the crib for ignite the wood crib.

A thermocouple (TC) tree with seven thermocouples was set up. One TC was placed between the five and six layers of the crib in order to measure the temperature between the two wood surfaces. One is placed on the upper surface of the crib. The remainders were set above the wood surface at $20 \mathrm{~cm}$ intervals to measure air temperatures.

BTP was hydrophobic, which was insoluble in water. In the experiments, BTP and water were contained in two respective $6.0 \mathrm{~L}$ tanks, and then discharged from one nozzle. The two fire suppressants of water and BTP were contained in two $6.0 \mathrm{~L}$ tanks, respectively. In each test, $5.0 \mathrm{~L}$ water and BTP was added into the container and pressurized by nitrogen to the assigned gauge pressure of $0.4 \mathrm{MPa}$, respectively. The discharge nozzle contained four circular orifices with the diameter of $0.5 \mathrm{~mm}$. The droplet size of water 
mist was about $150 \mu \mathrm{m}$ at $0.4 \mathrm{MPa}$ as measured by shadowgraphy techniques. The flow rate of water mist and BTP was about $0.12 \mathrm{~L} / \mathrm{s}$ and $0.10 \mathrm{~L} / \mathrm{s}$ at $0.4 \mathrm{MPa}$, respectively. The distance from the nozzle the wood surface was set as $0.5 \mathrm{~m}$. The suppressant was discharged from the top and then one side to another, making sure the flame on one side was extinguished before moving on to the other side. The discharging was continuous, and no discharge was directed at the back and bottom of the crib.

In each test, $100 \mathrm{ml}$ of gasoline was poured into the pan located under the wood to ignite the wood cribs. After burning for $60 \mathrm{~s}$, the wood crib was ignited. Then the gasoline pan was removed. The wood cribs was left to burn freely for $210 \mathrm{~s}$ before discharging suppressants.

The experimental process was recorded by a video with the rate of 24 frames per second. The fire extinguishing time was determined from the video record. Mass of BTP consumed in the test was measured through an electric scale with an accuracy of $0.01 \mathrm{~g}$. Each test was repeated three times to get an average value. Measurement uncertainty of flame temperature, fire extinguishing time, mass of agents and $\mathrm{HF}$ concentration were estimated to be $\pm 5 \%, \pm 5 \%, \pm 10 \%$ and $\pm 10 \%$, respectively.

For measuring the HF concentration, a gas sampling tube was placed near the wood crib with $1.6 \mathrm{~m}$ height above the floor with the horizontal distance to the wood crib center of $0.8 \mathrm{~m}$. Two kinds of gas samples were collected. Each sample was continuous collected for $1 \mathrm{~min}$. The first began at the time of discharging suppressant. After stopping suppressant discharge for $5 \mathrm{~min}$, another sample collection began. The gas was absorbed by $\mathrm{NaOH}$ aqueous solution. Concentration of fluorine ions was measured by chemical ion chromatography.

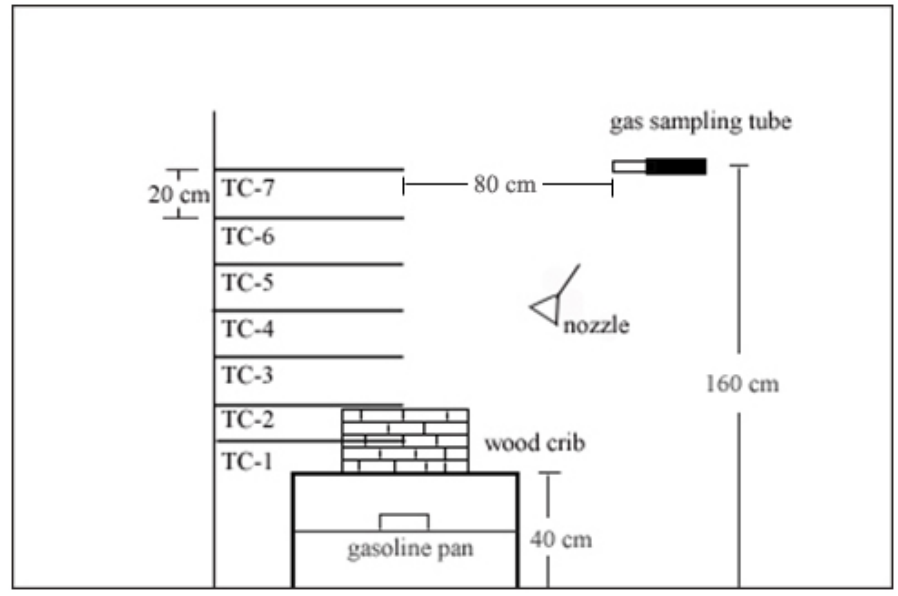

Fig. 1. Schematic illustration of experimental setup.

\section{WOOD CRIB FIRES}

Before the suppressing tests, characteristics of the wood crib fire were studied. Mass loss rate of the wood cribs was studied by measuring the weight change of the wood cribs in burning. It was found that the wood crib fires grew quickly after being ignited by gasoline pool fire. It took approximately 5 min for the crib to be reduced to $55 \%$ of its original mass. The flame is as high as $1.0 \mathrm{~m}$ with peak temperature of about $850^{\circ} \mathrm{C}$. The average loss rate is about $7.4 \mathrm{~g} / \mathrm{s}$ and the heat release rate is estimated as $96.6 \mathrm{~kW}$ according to the reference [19]. 


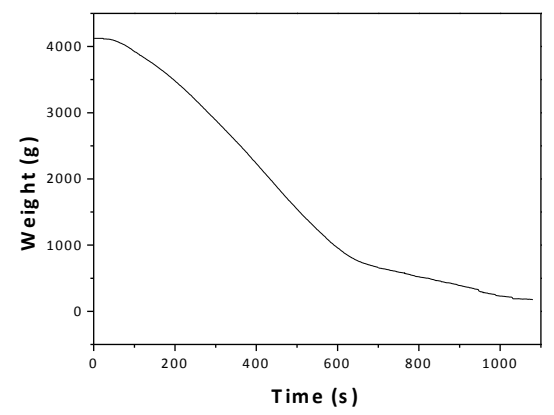

Fig. 2. Timed mass loss of the wood crib during free burning process

\section{SUPPRESSION TESTS}

A total of four kinds of experiments were conducted to suppress the wood crib fires. Test A discharged water mist alone (denoted as WM). Test B discharged BTP alone (denoted as BTP). Test C discharged BTP first and water mist followed (denoted as BTP/WM). Test D sprayed BTP and water mist simultaneously (denoted as BTP-WM). Test conditions, sequence and results were summarized and listed in Table 1.

Table 1. Experimental results of the four suppressing tests.

\begin{tabular}{|c|c|c|c|c|c|c|c|c|}
\hline \multirow[t]{2}{*}{ Tests } & \multirow[t]{2}{*}{ Conditions } & \multirow[t]{2}{*}{ Observations } & \multicolumn{2}{|c|}{$\begin{array}{c}\text { Extinguishing } \\
\text { time } \\
(\mathrm{s}, * \pm 5 \%)\end{array}$} & \multicolumn{2}{|c|}{$\begin{array}{l}\text { Agent consumed } \\
(\mathrm{kg}, * \pm 10 \%)\end{array}$} & \multicolumn{2}{|c|}{$\begin{array}{l}\text { HF concentration } \\
(\mathrm{ppm}, * \pm 10 \%)\end{array}$} \\
\hline & & & $\mathrm{t}_{\mathrm{F}}{ }^{\mathrm{a}}{ }^{\mathrm{S}, *}$ & $\begin{array}{l}5 \% \text { ) } \\
t_{C}{ }^{b}\end{array}$ & & & $\mathrm{C}_{\mathrm{S}}^{\mathrm{e}}$ & $\mathrm{C}_{\mathrm{E}}^{\mathrm{f}}$ \\
\hline $\mathrm{A}$ & WM alone & Extinguished & 35.0 & 44.0 & 0 & 4.54 & 0 & 0 \\
\hline B & BTP alone & Re-ignited 16s later & 5.0 & --- & 0.82 & 0 & 382 & 173 \\
\hline $\mathrm{C}$ & $\mathrm{BTP} / \mathrm{WM}$ & Extinguished & 4.0 & 14.0 & 0.76 & 1.78 & 121 & 40 \\
\hline $\mathrm{D}$ & BTP-WM & Extinguished & 6.0 & 26.0 & 1.84 & 2.30 & 168 & 76 \\
\hline
\end{tabular}

\footnotetext{
* uncertainty of the data measured in the experiments

a: $t_{F}$ - flame extinguishing time

$\mathrm{b}: \mathrm{t}_{\mathrm{C}}-$ complete extinguishing time without glowing combustion

$\mathrm{c}: \mathrm{m}_{\mathrm{B}}-$ mass of BTP consumed in the test

$\mathrm{d}$ : $\mathrm{m}_{\mathrm{W}}-$ mass of water consumed in the test

e: $\mathrm{C}_{\mathrm{s}}$ - concentration of HF during suppressant discharging process

f: $C_{E}$ - concentration of HF 5 min after stopping the suppressant discharging
}

It was shown that water mist discharged at the pressure could extinguish fire, but a relatively long time of $44 \mathrm{~s}$ was needed and $4.54 \mathrm{~kg}$ water was consumed. For BTP, it could fast extinguish the flame in $5 \mathrm{~s}$, proving its high efficiency in fire suppression. But the wood was reignited $16 \mathrm{~s}$ later, indicating that glowing combustion was still in processing after flame knockdown. In test C, with BTP discharged before water mist, the fire extinguishing performance was obviously improved. The first discharged BTP extinguished the flame in $4 \mathrm{~s}$, the following water mist extinguish the glow combustion in $12 \mathrm{~s}$. The fire could be fully extinguished in $18 \mathrm{~s}$ with $0.76 \mathrm{~kg}$ BTP and $1.78 \mathrm{~kg}$ water consumed. As to the simultaneous application of BTP and water mist, the flame was knockdown in 6 s and the complete extinguishment time was $26 \mathrm{~s}$ with $1.84 \mathrm{~kg}$ BTP and $2.30 \mathrm{~kg}$ water consumed.

To study the suppression process in details, variations of flame temperatures and flame shapes in the tests were recorded as shown in Fig. 3-4. As shown by the temperature curves of Fig. 3, in test A, the flame 
temperatures decreased rapidly once water mist was discharged out. The temperature kept decreasing until total extinction for the continuous discharging of water mist. Photographs of the tests showed that once the wood was contacted with water mist, the flame was controlled and not any flare up was observed, different to that seen in liquid pool fires [15]. Much smoke was produced, but the room clear up soon after the fire was fully extinguished. In test B, due to that the flame was fast extinguished, the TC temperatures decreased rapidly. But soon the flame re-grew to full strength, and the temperature detected by the thermocouples sharply increased, correspondingly. It was observed that in Fig. 3C, the temperature of TC-1 decreased slightly after the flame extinguishment, showing that of the wood surface was still very hot even after the flame was inhibited. Comparing the timed images of test B with Test A, more smoke was produced when BTP acted on the flame. In test $\mathrm{C}$, the TC-1 profile was different to the behavior in other three tests. It was possible that TC-1 in test $\mathrm{C}$ was attached to the wood stick. As revealed by the images in test $\mathrm{C}$, the smoke generated during the BTP discharging was much reduced in the following water discharging. Similar to test A and C, the TC temperatures of test D decreased rapidly after the mixed suppressant was sprayed out. No re-strike occurred under the continuous attack of the composite fire suppressants. In all the cases, the cribs were kept integrity without obvious collapse or damage after fire extinguishment.
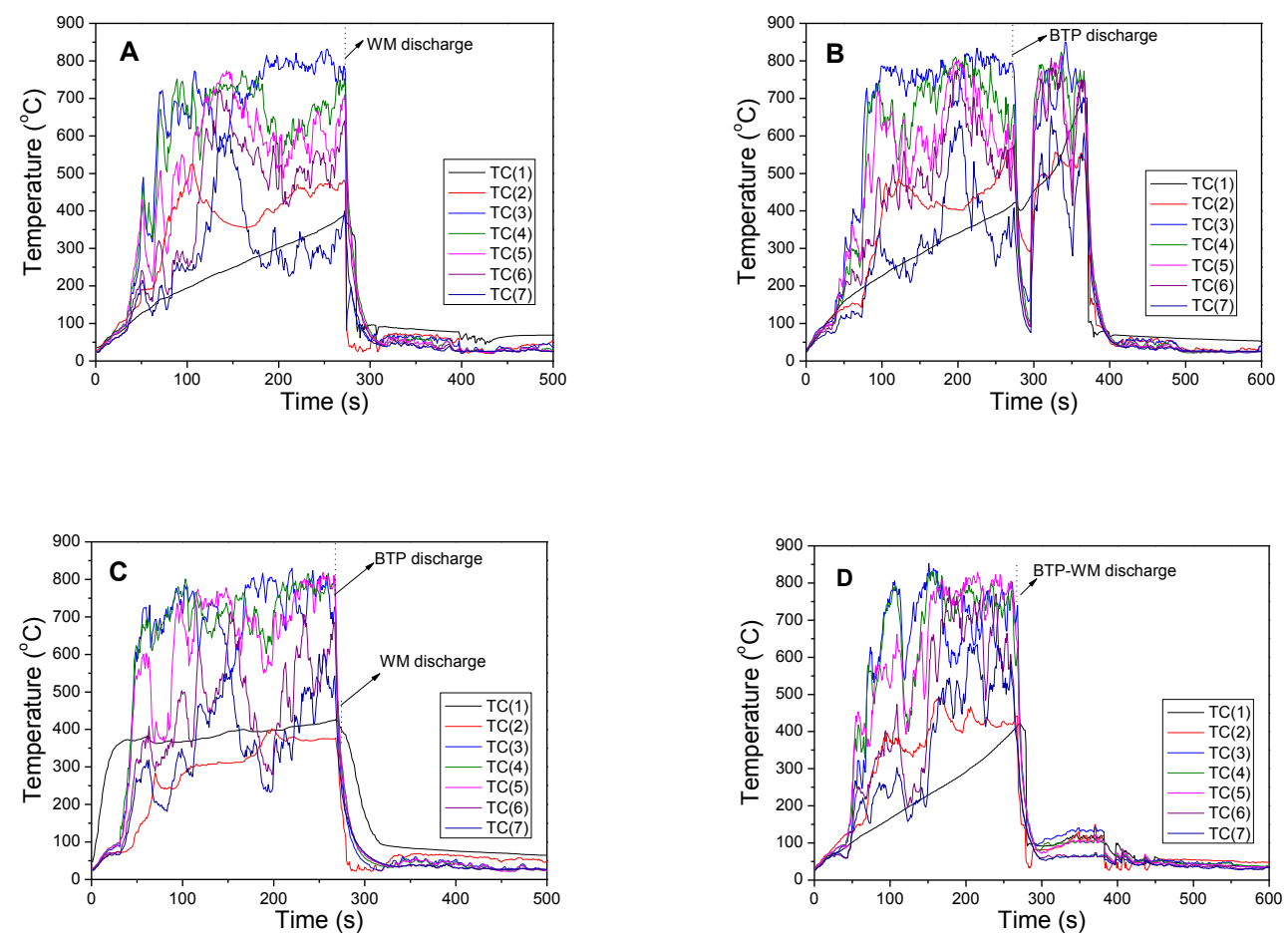

Fig. 3. Temperature curves of the TCs for tests A to D. 

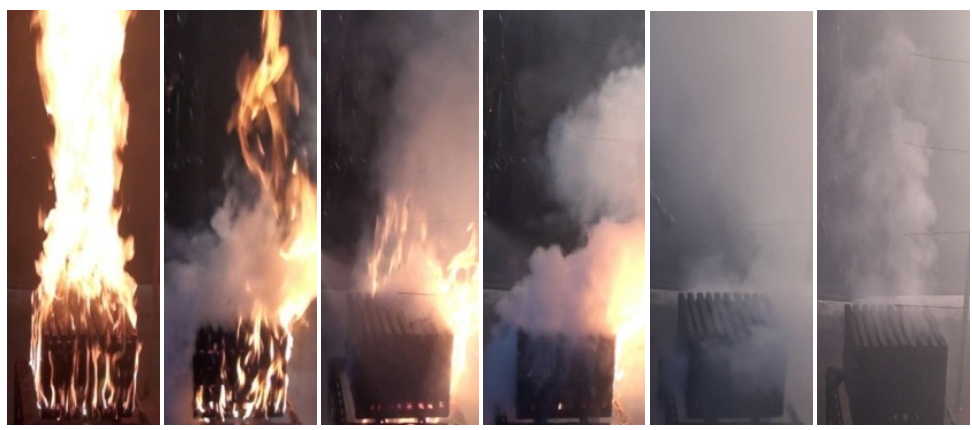

Test A

$2 \mathrm{~s}$

$20 \mathrm{~s}$

$30 \mathrm{~s}$

$35 \mathrm{~s}$

$44 s$
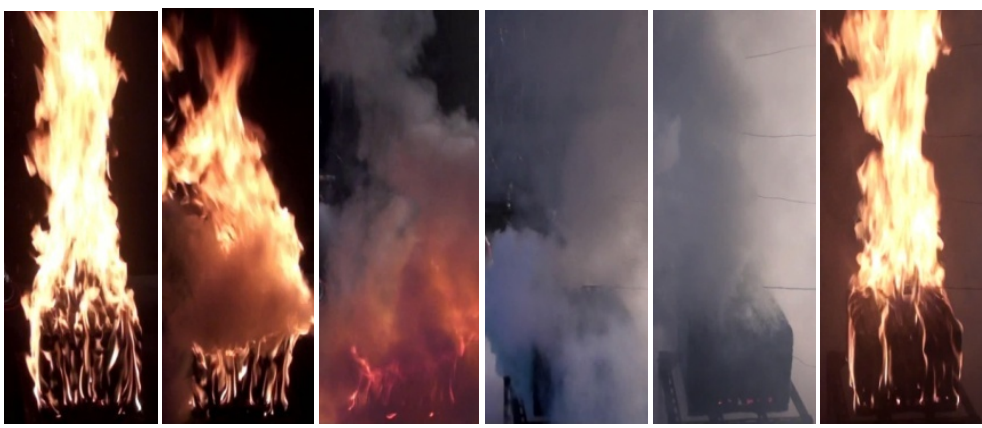

Test B

$0 \mathrm{~s}$

$1 \mathrm{~s}$

$3 \mathrm{~s}$

$5 \mathrm{~s}$

$10 \mathrm{~s}$

$16 \mathrm{~s}$
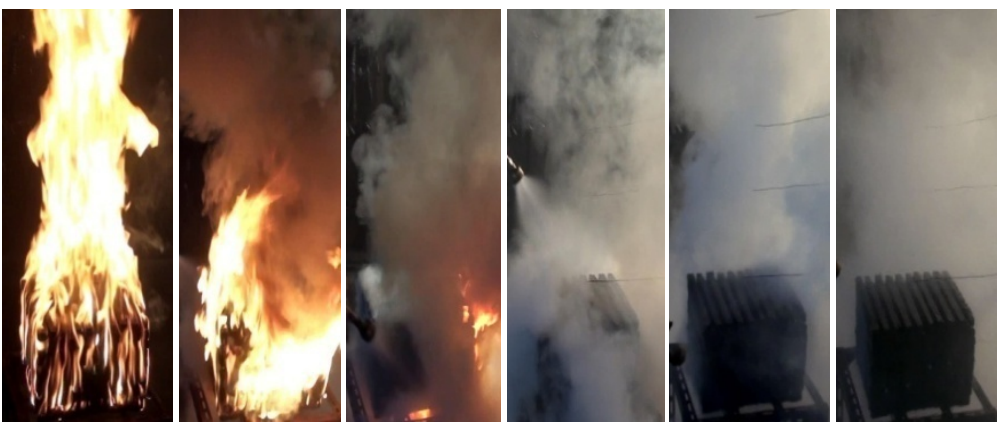

Test C

$0 \mathrm{~s}$

$1 \mathrm{~s}$

$3 \mathrm{~s}$

$4 \mathrm{~s}$

9s

$14 \mathrm{~s}$

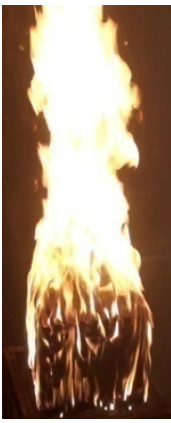

$0 \mathrm{~s}$

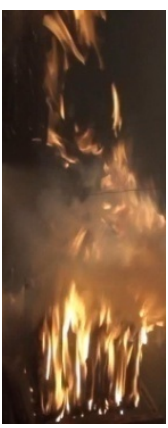

$1 \mathrm{~s}$

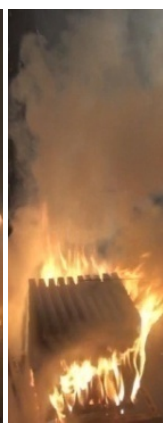

$3 \mathrm{~s}$

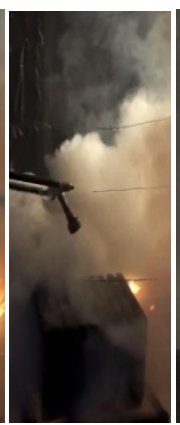

$5 \mathrm{~s}$

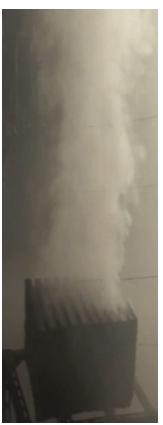

$6 s$

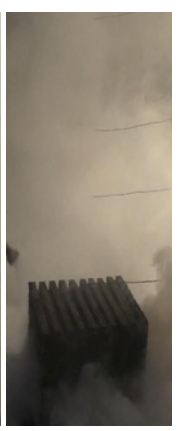

$26 \mathrm{~s}$

Fig. 4. Typical timed photographs for test A-D

\section{HF CONCENTRATION}

The amount of hydrogen fluoride (HF) produced in the fire suppression process is a safety concern, because $\mathrm{HF}$ is a highly corrosive gas that causes severe sensory irritation in humans [20]. BTP is always regarded as a clean gas fire suppressant, but as a fluorinated halocarbon, HF byproducts will be unavoidably 
generated in the interaction of BTP and fire. Table 1 listed the HF concentration measured during the fire suppression process $\left(\mathrm{C}_{\mathrm{S}}\right)$ and the one measured 5 min after stopping the discharging of suppressant $\left(\mathrm{C}_{\mathrm{E}}\right)$. In test A with water mist used, not any HF was detected. In test B with BTP used alone, high HF concentration of $382 \mathrm{ppm}$ was produced during the fire suppression process. Such a concentration decayed about half of the peak value 5 min later. As for test $\mathrm{C}$ with water mist discharged after BTP, the peak HF concentration was only $121 \mathrm{ppm}$, about one third of test A, and decreased to $40 \mathrm{ppm}$ after fire extinguishment. In test $\mathrm{D}$, the Cs value was $178 \mathrm{ppm}$, higher than that of test $\mathrm{C}$, but lower than that of test B. After fire extinguishment, the $C_{E}$ value was measured as $76 \mathrm{ppm}$. Considering that the allowable level of HF concentration in the occupied room for re-entry by equipped response personnel is assumed as $90 \mathrm{ppm}$ [21], the HF concentration in test $\mathrm{C}$ and $\mathrm{D}$ were both acceptable. Fig. 5 compared the mass of HF produced per unit mass of suppressant of BTP during the discharging process $\left(\mathrm{R}_{\mathrm{S}}\right)$ and 5 min after stopping discharging $\left(\mathrm{R}_{\mathrm{E}}\right)$. It was shown that Rs of test $\mathrm{B}$ was $466 \mathrm{ppm}$ per $\mathrm{kg}$. While in test $\mathrm{C}$ and $\mathrm{D}$, Rs sharply decreased to 159 and $91 \mathrm{ppm}$ per $\mathrm{kg}$. The values of $\mathrm{R}_{\mathrm{E}}$ exhibited the similar varying trend that test $\mathrm{C}$ and $\mathrm{D}$ showed much lower $\mathrm{R}_{\mathrm{E}}$ values than that of test $\mathrm{B}$.

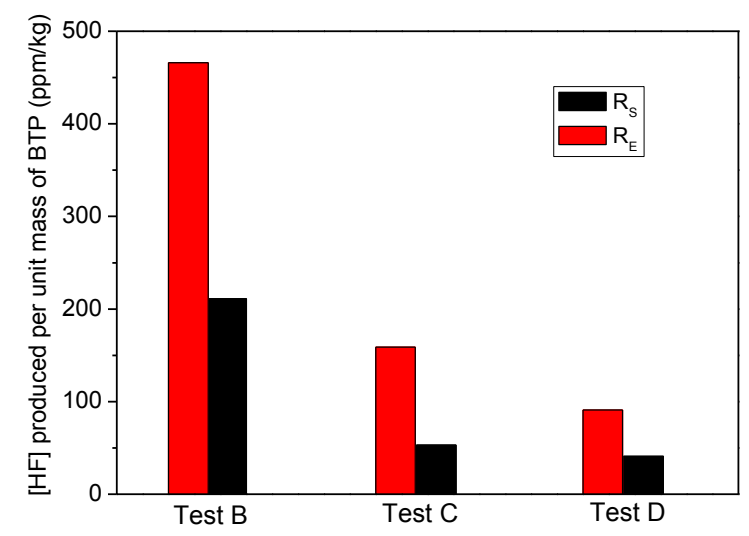

Fig. 5. HF concentration produced per unit mass of BTP in test B D.

It was known that the HF concentration greatly depends on the agent amount, fire size, compartment volume and fire extinguishing time, etc [22]. Comparing the values of test $\mathrm{C}$ and $\mathrm{D}$ with that of $\mathrm{B}$, it was considered that water mist greatly decreased HF concentration generated in fire suppression with the other conditions of fire size and compartment volume same. Such phenomenon was in agreement with the results reported by others that water mist could scrub HF from the air. In test B and C, similar amount of BTP was discharged into the fires, but much lower HF concentration was generated for the effect of water mist. In test D, more BTP was discharged into the fire, but water mist was discharged simultaneously with BTP, therefore, HF produced from BTP could be scavenged immediately. Meanwhile, the cooperation of water mist cooled the wood surface, and correspondingly fire size was reduced. Thus it reduced the decomposition of BTP and may also contribute to the reduction of HF concentration.

\section{DISCUSSION ON THE FIRE SUPPRESSION MECHANISM}

For deep seated wood crib fires, fuel supply is controlled by the positive feedback of heat from the products of its own combustion [3,11]. The supply of gaseous volatiles is produced via this feedback of thermal energy, which is dominated by thermal radiation from turbulent diffusion flames. As discussed by Bryan, the most important factor that determining the degree of difficulty in extinguishing a wood fire was the total thermal content of the crib. The flames were both the greatest source of heat from a wood fire and the easiest component to extinguish. Once the gas phase combustion is suppressed, a second combustion mechanism takes over if the heat content/temperature of the crib is sufficient. This glowing combustion of 
the remaining cellulosic char actually is a slow heterogeneous reaction involving the oxidation of carbon. It is nevertheless sufficiently exothermic to bring the temperature of the char up to red heat. If not stopped, this glowing combustion will propagate and the conducted and radiated heat may be sufficient to cause ignition of unpyrolyzed wood and a re-strike will occur. As a result, for completely extinguished deep seated wood crib fire, not only the flame was extinguished, more important, the glowing combustion must be stopped effectively.

The principal action of water mist in suppressing wood crib fires, is removal of heat from the fire through their heat capacity and latent heat of vapourisation [23]. The most important mechanism is physical cooling the wood surface to reduce the pyrolysis rate and so the rate of fuel supply to flame zone and thus reducing the heat release rate and the radiative feedback from the flame to the fuel surface. For water mist, it had two disadvantages in extinguishing deep seated wood crib fires. First, water mist with relatively small momentum was hard to penetrate the flame plume to reach the crib and could not effectively exert its role of cooling the wood surface. On the other hand, a long time discharging is needed for completely extinguish the glowing combustion. Water droplets have difficult access to the central sticks. Extinguishment of the inner core of the structure could only be achieved through dripping from the top layer of the crib after they had been saturated by water. Even though water was applied to the crib from the sides, the extinguishment of the interior of the densely packed cribs was mainly obtained through water dripping from the top layer [7]. As a consequence, at low and intermediate flow rates, water mist had to be kept on for a long time after extinguishment of the outer layers of the crib, in order to suppress the glowing combustion in the core. In our experiments, it takes about $44 \mathrm{~s}$ for water mist to extinguish the wood crib fires. Based on the fire extinguishing time and mass of agents consumed, the average water flux for the wood crib could be estimated as $48.7 \mathrm{~g} / \mathrm{m}^{2} \cdot \mathrm{s}$. While the critical water fluxes to the wood crib was calculated as $2.35 \mathrm{~g} / \mathrm{m}^{2} \cdot \mathrm{s}$ according to the method reported by Novozhilov and coworkers [24]. Such a big difference could be ascribed to the discrepancy in the practical experimental conditions and the ideal state of the model. The model assumed that the all the water discharged onto the wood cribs were fully utilized for fire suppression. In practical, not all the water discharged out was efficient and there must be a certain amount of water flew out from the crevices of the wood cribs and became "inefficient" for fire suppression. It would result in the increase of water flux required for fire suppression.

Different to that of water mist, BTP extinguished fires through physical and chemical means, in which the chemical effect is dominant [17]. BTP acted as the physical suppressant through two methods of vaporization and dilution. When discharged from the tank, the BTP droplets would fast vaporize with an enthalpy of vaporization of $30.6 \mathrm{~kJ} / \mathrm{mol}$, which could decrease the flame temperature. Meanwhile, the BTP gas molecules could dilute the oxygen concentration. Then BTP gas would decompose in the flame and produce free radicals of $\mathrm{CF}_{3}$ and $\mathrm{Br}$, which removed the active $\mathrm{H}, \mathrm{OH}$ and $\mathrm{O}$ radicals in the combustion. The possible detailed chain reactions between BTP and flame radicals could be formulated as following [25]:

$$
\begin{aligned}
& \mathrm{CF}_{3} \mathrm{CBrCH}_{2} \rightarrow \mathrm{Br}+\mathrm{CF}_{3}+\mathrm{C}_{2} \mathrm{H}_{2} \\
& \mathrm{H}+\mathrm{HBr} \rightarrow \mathrm{H}_{2}+\mathrm{Br} \\
& \mathrm{CF}_{3}+\mathrm{O} \rightarrow \mathrm{CF}_{2} \mathrm{O}+\mathrm{F} \\
& \mathrm{CF}_{2} \mathrm{O}+\mathrm{H} \rightarrow \mathrm{FCO}+\mathrm{HF} \\
& \mathrm{CF}_{2}+\mathrm{H} \rightarrow \mathrm{CF}+\mathrm{HF} \\
& \mathrm{FCO}+\mathrm{OH} \rightarrow \mathrm{CO}_{2}+\mathrm{HF} \\
& \mathrm{F}+\mathrm{H} \rightarrow \mathrm{HF}
\end{aligned}
$$

$$
\begin{aligned}
& \mathrm{Br}+\mathrm{H} \rightarrow \mathrm{HBr} \\
& \mathrm{OH}+\mathrm{HBr} \rightarrow \mathrm{H}_{2} \mathrm{O}+\mathrm{Br} . \\
& \mathrm{CF}_{3}+\mathrm{H} \rightarrow \mathrm{CF}_{2}+\mathrm{HF} \\
& \mathrm{CF}_{2}+\mathrm{OH} \rightarrow \mathrm{FCO}+\mathrm{HF} \\
& \mathrm{FCO}+\mathrm{H} \rightarrow \mathrm{HF}+\mathrm{CO} \\
& \mathrm{CF}+\mathrm{OH} \rightarrow \mathrm{CO}+\mathrm{HF}
\end{aligned}
$$

Here, the chemical suppressing action of BTP involved in reacting with a set number of flame radicals (e.g. $\mathrm{F}+\mathrm{H} \rightarrow \mathrm{HF}$ ); and chemical catalytic reacting with flame radicals via a catalytic cycle (e.g., $\mathrm{Br}+\mathrm{H} \rightarrow \mathrm{HBr}$, $\mathrm{HBr}+\mathrm{H} \rightarrow \mathrm{Br}+\mathrm{H}_{2}$ ) and thus further removing a large number of species required for flame propagation. 
A physical mechanism always produces linear, but inefficient suppression effectiveness, while catalytic reactions involving bromine containing suppressants produce high chemical effectiveness. The superior efficacy of BTP to water mist in quenching the flame of the wood cribs could be mainly ascribed to bromine-incurred catalytic scavenging of flame radicals. A contrast test was conducted with HFC-227ea as fire suppressant with other conditions same. It was found that the wood crib fires could not be completely extinguished by HFC-227ea and re-ignition occurred. Mass of HFC-227ea consumed for the first flame extinguishment was much more than that of BTP (seen the Table S1 in supplementary materials), revealing its less fire suppressing efficiency than that of BTP. Such difference between BTP and HFC-227ea may partly prove the important role of bromine in the chemical fire suppression process.

Although BTP showed high efficiency in flame extinguishment, however, it could not effectively inhibit the deep seated wood crib fires. BTP is a liquid with boiling point of $34^{\circ} \mathrm{C}$. After flame extinguishment, the more discharged BTP would rapidly transform into gas and run away. In such a room with natural ventilation, the glowing combustion of wood cribs could not be inhibited by BTP, even under long time discharging. In test $\mathrm{C}$, after the flame was extinguished by BTP, the following water mist exerted its cooling effect for inhibiting the glowing combustion to acquire a full extinguishment. Improved fire suppression effectiveness was exhibited by the BTP-water mist conjunction applications.

In the real fire scenes, rapid extinction of flames by chemical means would be very advantageous to the fire fighter, allowing access to the root of the fire and therefore more rapid and complete extinction would be possible [7]. This is one of the current goals of the study, to identify a fire suppression method that combine the rapid flame knockdown of a chemical acting agent with the extensively used Class A suppressant of water mist with high physical cooling capacity.

\section{CONCLUSION}

Performance of the combination of bromofluoropropene and water mist in suppressing deep seated wood crib fires were examined by laboratory scale fire suppression tests. Results showed that the combination of the two clean agents exhibited the advantages to solely use of BTP or water mist.

- The combination of BTP and water mist could extinguish deep seat wood crib fires with relatively shorter time and less suppressing agents. The first discharged BTP could fast extinguish the flame and the following water mist could effectively cool the hot wood surface and extinct the glowing combustion, preventing the re-strike.

- The use of BTP with water mist could decrease the HF concentration in the room to acceptable level for water mist could scribing acid gas from the air.

- The two clean agents are both liquid at room temperature, which could be discharged at the same discharging system. Such combination is easy to realize and operate. It would not increase the engineering cost, showing prospective in practical applications.

As to the simultaneous discharging of BTP and water mist, the present experimental and analysis is qualitative and fundamental, and a systematic quantitative research is in progress.

\section{ACKNOWLEDGEMENT}

The work described in this paper was supported by a project of National Natural Science Foundation of China (No.51004088 and No.51276176) and new teacher foundation of the Ministry of Education of China (No.20103402120005).

\section{REFERENCES}

[1] Xu, Q., Griffin, G. J., Jiang, Y., Preston, C., Bicknell, A. D., Bradbury, G. P., and White, N., (2008) Study of Burning Behavior of Small Scale Wood Crib with Cone Calorimeter, Journal of Thermal Analysis and Calorimetry, 91(3):787-790, http://dx.doi.org/10.1007/s10973-007-8338-7 
[2] White, R.H., Wood Handbook, Chapter 18: Fire Safety of Wood Construction.

[3] Drysdale, D.D., (1998) Introduction to Fire Dynamics, 2nd edn. New York: Wiley.

[4] Cox C, editor, (1995) Combustion Fundamentals of Fire. New York: Academic Press.

[5] Bryan, J., and Smith, D. N., (1945) The Effect of Chemicals in Water Solution on Fire Extinction, Engineering, 159, Part I, 457, Part II, 497.

[6] Chattaway, A., Cox, G. G., Preece, S. R., and Spring, D. J., (1997) The Development of a Small Class A Fire Test, Halon Options Technical Working Conference, 6-8 May 1997, 498-508.

[7] Tamanini, F., (1976) The Application of Water Sprays to the Extinguishment of Crib Fires, Combustion Science and Technology, 14:17-23. DOI: 10.1080/00102207608946742.

[8] Walton, W. D., (1998) NBSIR 88-3696, Suppression of Wood Crib Fires with Sprinkler Sprays: Test Results.

[9] Chen. L.V., Zhu, W., Cai, X., Pan, L. W., and Liao, G. X., (2009) Experimental Study of Water Mist Fire Suppression in Tunnels under Longitudinal Wentilation, Building and Environment, 44(3): 446455, http://dx.doi.org/10.1016/j.buildenv.2008.04.005

[10] Cai, X, Wang, X. S. , Liang, T. S., and Liao, G. X., Experimental Study on the Effects of Low Ambient Pressure Conditions at High Altitude on Fire Suppression with Water Mist, (2010) Journal of Fire Sciences, 28(5), 441-458, DOI: 10.1177/0734904110361311

[11] Granta, G., Brentonb, J, and Drysdale, D., (2000) Fire Suppression by Water Sprays, Program Energy Combust Science, 26(2),79-130, http://dx.doi.org/10.1016/S0360-1285(99)00012-X

[12] Levendis, Y. A., and Delichatsios, M. A., Cryogenic suppression of liquid pool fires and wooden crib fires, http://www.nfpa.org/assets/files/PDF/Proceedings/SUPDET11LevendisPaper.pdf

[13] Kim, A., and Crampton, G., (2012) Fire Suppression Performances of Manually Applied CAF and other Water Based Systems, Fire Technology, 48(3):549-564. DOI: 10.1007/s10694-009-0119-3

[14] Trevits, M.A., Smith, A.C., Urosek, J. E., and Valoski, M. P., Evaluation of Deep-Seated CribBlock Fires and Direct Application of Fire Suppression Agents, http://stacks.cdc.gov/view/cdc/8715/

[15] Liu, Z.G., Kim, A.K., Carpenter, D., (2007) A Study of Portable Water Mist Fire Extinguishers Used for Extinguishment of Multiple Fire Types, Fire Safety Journal, 42(1): 25-42.

DOI: 10.1016/j.firesaf.2006.06.008

[16] Zhou, X.M., Liao, G.X., and B. Cai, (2006) Improvement of Water Mist's Fire-Extinguishing Efficiency with MC Additive, Fire Safety Journal 41 (1): 39-45, http://dx.doi.org/10.1016/j.firesaf.2005.08.004

[17] Mather, J.D., and Tapscott, R.E. Environmentally Acceptable Fire Suppressants. NIST GCR 06-901, 2007, p. 72.

[18] Ni, X.M., Chow, W. K., (2011) Performance Evaluation of Water Mist with Bromofluoropropene in Suppressing Gasoline Pool Fires, Applied Thermal Engineering 31 (17-18):3864-3870, http://dx.doi.org/10.1016/j.applthermaleng.2011.07.034

[19] Xu, Q., Griffin, G. J., Jiang, Y., Bicknell, A. D., Bradbury, G. P. , White, N., (2008) Calibration Burning of Wood Crib Under ISO9705 Hood, Journal of Thermal Analysis and Calorimetry, 91 (2):355-358, http://dx.doi.org/10.1007/s10973-007-8272-8

[20] M. Meldrum, (1993) Toxicology of substance in Relation to Major Hazards: Hydrogen Fluoride, Health and Safety Executive, ISBN 01188210008.

[21] Sheinson, R.S., Ayers, S., Anleitner, R., and Maranghides, A.(2004) Heptafluoropropane with Water Spray Cooling System as a Total Flooding Halon 1301 Replacement: System Implementation Parameters, in: Halon Options Technical Working Conference, 14th Proceedings, May 4-6, Albuquerque, New Mexico, 1-10.

[22] Burch, I. (2007) The Effects of Water Spray Cooling in Conjunction with Halogenated Extinguishants on Hydrogen Fluoride Generation and Decay. Defense Science and Technology Organisation of 
Australian Government, DSTO-TR-1982, 1-16.

[23] Fristrom, RM. Combustion Suppression, (1967) Fire Research Abstracts and Reviews, 9:125-160.

[24] Novozhilov,V., Moghtaderi, B., Kent, J.H., and Fletcher, D.F. (1999) Solid fire extinguishment by a water spray, Fire Saf. J, 32:119-135. http://dx .doi.org/10.1016/S0379-7112(98)00036-8

[25] Ni, X.M., Chow, W. K., Li, Q. W., Tao, C. F., (2010) Experimental Study of New Gas-Solid Composite Particles in Extinguishing Cooking Oil Fires, 29(2):152-176.

http://dx.doi.org /10.1177/0734904110385064. 